\title{
Effect of foliar or soil application of selenium on some morphological and physiological traits of garden pansy (Viola $x$ wittrockiana Gams) grown under salinity stress
}

\author{
Farima JAVADI ${ }^{1}$, Sepideh KALATEJARI ${ }^{1}$, Marjan DIYANAT ${ }^{1,2}$
}

Received February 1, 2020; accepted April 11, 2020.

Delo je prispelo 01. februarja 2020, sprejeto 11. aprila 2020

Effect of foliar or soil application of selenium on some morphological and physiological traits of garden pansy (Viola $x$ wittrockiana Gams) grown under salinity stress

Abstract: Salinity stress is one of the most important plant stresses in Iran. In this regard, a factorial experiment was conducted to investigate the effects of salinity stress on the garden pansy. The investigated factors were containing sodium selenate $\left(0,2,4\right.$ and $\left.8 \mathrm{mg} \mathrm{l}^{-1}\right)$, its method of application (foliar and soil applications) and salinity stress $\left(0,3\right.$ and $\left.6 \mathrm{dS} \mathrm{m}^{-1}\right)$. The obtained results indicated that salinity leads to the significant reduction in morphological traits, chlorophyll $\mathrm{a}$ and $\mathrm{b}$ contents. Under the salinity of $6 \mathrm{dS} \mathrm{m}^{-1}$, when sodium selenate was used in the soil, the fresh and dry mass of flower increased by 11.34 and $10.39 \%$, respectively, compared to the control. However, the use of sodium selenate by foliar application led to the increasing fresh and dry mass of garden pansy's flower by 25.10 and $25.41 \%$, respectively. Also, the content of chlorophyll a increased by $12.93 \%$ under the salinity of $6 \mathrm{dS}$ m-1 with applying $8 \mathrm{mg} \mathrm{l}^{-1}$ sodium selenate compared to the case of nonapplication. The superoxide dismutase activity decreased by $26.13 \%$ compared to the non-sodium selenate usage treatment. In conclusion the foliar application of sodium selenate at the concentraion of $8 \mathrm{mg} \mathrm{l}^{-1}$ resulted in the garden pansy's growth improvement.

Key words: garden pansy; superoxide dismutase; number of flowers; salinity stress; chlorophyll content
Učinek foliarnega dodajanja selena na nekatere morfološke in fiziološke lastnosti vrtne mačehe (Viola $x$ wittrockiana Gams) v razmerah slanostnega stresa

Izvleček: Slanostni stres je eden najpomembnejših stresov za rastline v Iranu. V tem pogledu je bil izveden faktorski poskus za preučevanje vpliva slanostnega stresa na vrtno mačeho. Preučevani so bili naslednji parametri: koncentracija natrijevega selenata $\left(0,2,4\right.$ in $\left.8 \mathrm{mg} \mathrm{l}^{-1}\right)$, način njegove uporabe (foliarno in talno dodajanje) in velikost slanostnega stresa $(0,3$ in $6 \mathrm{dS}$ $\left.\mathrm{m}^{-1}\right)$. Rezultati so pokazali, da je slanostni stres vodil $\mathrm{k}$ značilnemu zmanjšanju morfoloških latnosti in vsebnosti klorofila a in b. V razmerah slanostnega stresa $6 \mathrm{dS} \mathrm{m}^{-1}$ in ob talni uporabi natrijevega selenata sta se sveža in suha masa cvetov povečali za 1,34 in $10,39 \%$ v primerjavi s kontrolo. Foliarno dodajanje natrijevega selenata pa je povečalo svežo in suho maso cvetov vrthe mačehe za 25,10 in 25,41 \%. Tudi vsebnost klorofila a se je v razmerah slanosti $6 \mathrm{dS} \mathrm{m}^{-1}$ in uporabi natrijevega selenata $8 \mathrm{mg}$ $\mathrm{l}^{-1}$ povečala za $12,93 \% \mathrm{v}$ primerjavi $\mathrm{z}$ razmerami brez dodatkov selenata. Aktivnost superoksid dizmutaze se je pri dodatku selena zmajšala za $26,13 \% \mathrm{v}$ primerjavi $\mathrm{z}$ obravnavanjem brez selenata. Zaključimo lahko, da je foliarno dodajanje natrijevega selenata v koncentraciji $8 \mathrm{mg} \mathrm{l}^{-1}$ izboljšalo rast vrtne mačehe.

Ključne besede: vrtna mačeha; superoksid dismutaza; število cvetov; slanostni stres; vsebnost klorofila

1 Islamic Azad University, Science and Research Branch,Department of Agricultural Sciences and Food Industries, Tehran, Iran

2 Corresponding author, e-mail: Ma_dyanat@yahoo.com 


\section{INTRODUCTION}

Viola $x$ wittrockiana Gams, a garden pansy, (from Violaceae family) is of great economic importance. It contains salicylic acid, phenolic acids such as caffeic acid and their derivatives (Vukics et al., 2008). Garden pansy is used to decorate urban green spaces and to promote the mental well-being of citizens, but it experiences all kinds of environmental stresses such as drought, salinity, high temperature and cold.

Among the various stresses, salinity is one of the most important ones which severely restrict the productivity, especially in the arid and semi-arid regions (Ashraf \& Harris, 2004). According to the conducted studies, 30 and $50 \%$ of the agricultural ground will be destroyed by salinity within the next 25 years and by the middle of the $21^{\text {st }}$ century, respectively and this will have negative effects on the agricultural production (Shahid et al., 2018). Salinity stress is a serious environmental threat to the agricultural fields, which causes green fields to become arid and non-cultivable lands and reduces the plant growth and crop yield (Khan et al., 2015). The salinity stress is mostly obtained by high concentrations of sodium $\left(\mathrm{Na}^{+}\right)$and chloride $\left(\mathrm{Cl}^{-}\right)$ions within the soil solution (Hasegawa et al., 2000). High salinity results into the ionic and osmotic stresses which lead to the plant death as a consequence (Hu \& Schmidhalter, 2005; Mahajan et al., 2005). Furthermore, salinity stress yields yellow and brown flowers and therefore the ornamental value of the plants is reduced (Cassaniti et al., 2012; Matraszek et al., 2015). This stress causes premature aging of the leaves, chloroplast damage and chlorophyll content reduction. Chlorophyll decrement results in reduced photosynthesis and plants which maintain more chlorophyll content during the stress, have higher photosynthetic efficiency and are tolerant to the stress (Sharma \& Dubey, 2005). In salt tolerance, numerous compounds such as sugars, organic acids and nitrogen-containing ones such as amino acids, amides, imides and proteins act as osmotic adjusters. These compounds help maintain turgor pressure, cell volume and reduce the stress effects (Ashraf \& Harris, 2004). Various methods are available for reducing the salinity effects. Many researchers have examined the organic and inorganic substances in order to reduce the effects of salt toxicity (Liang et al., 2006; Ashraf et al., 2010; Hasanuzzaman et al., 2013; Diao et al., 2014). In a study by Satyendra et al. (1999) a positive correlation was observed between the peroxidase enzymes activities and soil salinity.

Selenium is an essential micronutrient for humans and animals (Matos et al., 2017; Supriatin et al., 2015). Although sodium selenate is unevenly distributed around the globe, its concentration ranges from 0.1-
$1 \mathrm{mg} \mathrm{kg}^{-1}$ soil (Bocchini et al., 2018). This element can be useful or harmful to the plant depending on its concentration and type of the plant species (Draho novský et al., 2016). Germ et al. (2007) indicated that sodium selenate is dangerous to the plants at high concentrations but can have beneficial effects at lower ones. Recent studies have shown that sodium selenate plays an important role in the plant tolerance to the environmental stresses including salinity (Feng et al., 2013; Bocchini et al., 2018; Munshower et al., 2018; Shahid et al., 2018; Tan et al., 2018). Selenium is not an essential ingredient in the plants but acts as an antioxidant protecting plants against UV radiation regulates plant growth and protects them against pathogens (Kaur et al., 2014). It protects the cell membrane against the salinity stress conditions (HawrylakNowak, 2009). There are some evidence of the positive effects of selenium on the growth and performance of tomato (Solanum lycopersicum L.) (Diao et al., 2014; Zhu et al., 2016), lemon balm (Melissa officinalis L.) (Habibi \& Sarvary, 2015) and canola (Brassica napus L.) (Hashem et al., 2013; Bybordi, 2016) at low concentrations. Sodium selenate has beneficial effects on the plants' growth and tolerance to the stresses through increasing their antioxidant capacity (Hasanuzzaman et al., 2010; Djanaguiraman et al., 2005; Rios et al., 2009). Further to these applications, selenium increases the antioxidant acids such as salicylic acid, jasmonic acid and hormones such as ethylene (Hasanuzzaman et al., 2013).

Sodium selenate is considered as an effective micronutrient in reducing the non-biological stresses such as salinity. Selenium fertilizer is used in four ways including the seed soaking, seed dressing, foliar and soil applications. Nowadays, selenium application technology is used as foliar or base fertilizer to increase the selenium content within the crops (Pezzarossa et al., 2012). The aim of this study is to investigate the effect of sodium selenate and its application method on the garden pansy plant under the salinity stress conditions in Iran.

\section{MATERIALS AND METHODS}

\subsection{CULTIVATION AND TREATMENT OF PLANTS}

The present research aims to investigate the effect of sodium selenate in both foliar and soil applications on the ornamental garden pansy's flowers (Viola $x$ wittrockiana 'Queen Yellow Bee') under salinity stress using a factorial experiment in a completely randomized design with three replications conducted in the greenhouse of horticulture department of Science and Research Branch of Tehran, Islamic Azad University in 2019. The 4-leaf 
ornamental garden pansy transplants were prepared from the Flower and Plant Center of Mahalat city. The transplants were then transferred to the $15 \mathrm{~cm}$-diameter pots containing culture medium (a mixture of perlite and cocopeat at $70: 30$ ratios) and kept in the greenhouse for two weeks for adaptability. During this time period, they were fed with Hogland's nutrient solution to the amount of half of the recommended concentration with irrigation water once a week (Hoagland \& Arnon, 1950). EC of nutrient solution was 1-1.4 $\mathrm{ds} \mathrm{m}^{-1}$. Plants were treated with sodium chloride $(\mathrm{NaCl})$ at three levels of 0 (control), 3 and $6 \mathrm{dS} \mathrm{m} \mathrm{m}^{-1}$. Salinity treatments in volume of $50 \mathrm{ml}$ was irrigated regularly as required (every two weeks) and it was applied until complete flowering of the plant. Salt used in this experiment was purchased from Elgomhouria Company, Amiria, Cairo. The selenium concentrations of 0 (control), 2, 4 and $8 \mathrm{mg} \mathrm{l}^{-1}$ as sodium selenate $\left(\mathrm{Na}_{2} \mathrm{SeO}_{4}\right)$ have been applied in two ways of leaf foliar and soil applications. Leaf application was applied immediately after transplanting and continued every two weeks until the end of the experiment. The solution $\mathrm{pH}$ was initially adjusted between 5.8 and 6.5 with minute additions of $\mathrm{HCI}$ or $\mathrm{NaOH}$ as needed. Foliar application of sodium selenate was done in the evenings and $10 \mathrm{ml}$ volume was consumed for each pot. Two weeks after the last application of the treatments, leaf and root samples were collected in order to perform experiments. The average day and night temperatures were 15-25 and $12-15{ }^{\circ} \mathrm{C}$, respectively, relative humidity was about $60 \%$ and light to darkness estimated as 14 to $10 \mathrm{~h}$ with light intensity of $160 \mu \mathrm{mol} \mathrm{m} \mathrm{m}^{-2} \mathrm{~s}^{-1}$. Eight replicates (individual plants) were used for each treatment.

\subsection{MORPHOLOGICAL TRAITS MEASUREMENT}

The shoot height was measured by a ruler. Thus, from the plant's collar to the shoot apex was considered as the height of the shoot. The cultivated plants in each pot were cut from the collar section by scissors and shoot and flower were weighed. The fresh mass were measured using a digital scale with accuracy of $0.01 \mathrm{~g}$. After drying the different parts of plant in the oven at $72{ }^{\circ} \mathrm{C}$ for $24 \mathrm{~h}$, their dry mass were measured by digital scale.

\subsection{CHLOROPHYLL CONTENT MEASUREMENT}

The chlorophyll content measurement was carried out according to the method of Lichtenthaler and Wellburn (1983). At first, $0.1 \mathrm{~g}$ of the plant leaf sample was thoroughly grinded in Chinese mortar together with $3 \mathrm{ml}$ of $80 \%$ acetone and the extract's final volume reached
$15 \mathrm{ml}$. The extract was then filtered at the speed of $5000 \mathrm{~g}$ for $10 \mathrm{~min}$ using a centrifuge. The spectrophotometer device (Shimadzu UV-160) was utilized to measure the absorption rate of the samples. First, the apparatus was set to zero with $80 \%$ acetone and then the absorption rates of the extract were read by spectrophotometer at the wavelengths of 663 and $645 \mathrm{~nm}$ for chlorophyll a and b, respectively.

$$
\begin{aligned}
& \text { Chlorophyll } \mathrm{a}=(19.3 \mathrm{~A} 663-0.86 \mathrm{~A} 645) \mathrm{V} / 100 \mathrm{~W} \\
& \text { Chlorophyll } \mathrm{b}=(19.3 \mathrm{~A} 645-3.6 \mathrm{~A} 663) \mathrm{V} / 100 \mathrm{~W}
\end{aligned}
$$

\subsection{ASSESSMENT OF THE ENZYMES ACTICITY}

The catalase enzyme's activity was measured with spectrophotometry method and based on the absorption reduction of hydrogen peroxide for $30 \mathrm{~s}$ at a wavelength of $240 \mathrm{~nm}$. The reaction mixture contained $50 \mathrm{mM} \mathrm{K}$ phosphate buffer $(\mathrm{pH}=7), 15 \mathrm{mM}$ hydrogen peroxide and $100 \mu \mathrm{l}$ of enzyme extract. The reaction was started by adding hydrogen peroxide and the absorption reduction measured for $30 \mathrm{~s}$. The degraded amount of hydrogen peroxide was calculated using the extinction coefficient equal to $40 \mathrm{mM}^{-1} \mathrm{~cm}^{-1}$ (Velikova et al., 2001). The measurement of superoxide dismutase was conducted using the method presented in Giannopolitis and Ries (1977). To measure the activity of this enzyme, the reaction mixture was prepared in a final volume of $1 \mathrm{ml}$ including $50 \mathrm{mM}$ phosphate buffer $(\mathrm{pH}=7.8), 0.013 \mathrm{M}$ methionine, $0.01 \mu \mathrm{M}$ EDTA and $2 \mu \mathrm{M}$ riboflavin and maintained in the complete darkness. Immediately after adding riboflavin, $3 \mathrm{ml}$ of it was poured into the test tube and $100 \mu \mathrm{l}$ of protein sample added to each tube. The test tubes were placed in a distance of $30 \mathrm{~cm}$ from the light source and the samples' absorption values were read at the corresponding wavelength after 16 minutes. The device was calibrated at the wavelength of $560 \mathrm{~nm}$. The enzyme activity was expressed in enzyme unit per mg protein in each sample. The total protein content in the enzyme extracts was determined according to Bradford (1976) procedure, using bovine serum albumin as a standard.

\subsection{MEASURING CONCENTRATION OF ELE- MENTS}

To measure $\mathrm{Cl}^{-}, 100 \mathrm{mg}$ of powdered plant tissue was poured into the Falcone tube and extracting was performed after adding $10 \mathrm{ml}$ of $0.5 \mathrm{M}$ nitric acid and drying for $1 \mathrm{~h}$ at $80{ }^{\circ} \mathrm{C}$. The amount of $1 \mathrm{ml}$ of the extract was used for $\mathrm{Cl}^{-}$reading according to the colorimetry method 
at the wavelength of $480 \mathrm{~nm}$ using Epoch setup (Munns \& Tester, 2008). In order to measure the $\mathrm{Na}^{+}$and $\mathrm{K}^{+}$contents, the garden pansy's leaves were completely dried in open air after harvesting. The samples were then powdered using a mortar. $0.3 \mathrm{~g}$ of the powdered samples were weighed and converted into ash in the furnace at $500{ }^{\circ} \mathrm{C}$ for $6 \mathrm{~h}$ and then dissolved in $5 \mathrm{ml}$ of $2 \mathrm{M}$ nitric acid solution. The solution's volume was finally reached $25 \mathrm{ml}$ with double distillation water and filtered with Whatman No.1 filter paper. Then, measurement was performed using flame photometry device (PFP7 model manufactured by JENWAY Company, UK) (Chapman \& Pratt, 1962). The Unico spectrophotometer made in USA was used to measure the P concentration of the root and shoot. For this purpose, the plant samples were first converted into ash within the furnace $\left(550^{\circ} \mathrm{C}\right)$. Then, $1 \mathrm{ml}$ of Barton reagent and $70 \mathrm{ml}$ of $70 \%$ perchloric acid were added to the ash samples. After that, their volume reached 10 $\mathrm{ml}$ with double distillation water. The absorbance of each solution was measured by spectrophotometer at wavelength of $450 \mathrm{~nm}$ (Ryan et al., 2007). For measuring Se concentration, $5 \mathrm{~g}$ dried powder samples were digested with $25 \mathrm{ml}$ of a 4:1 mixture of $\mathrm{HNO}_{3}$ and $\mathrm{HClO}_{4}$ at $130{ }^{\circ} \mathrm{C}$ for $60 \mathrm{~min}$. After cooling, $5 \mathrm{ml}$ of concentrated $\mathrm{HCl}$ was added to the sample for reduction of $\mathrm{Se}^{+6}$ to $\mathrm{Se}^{+4}$ and continued for $20 \mathrm{~min}$ at $115^{\circ} \mathrm{C}$ until the sample was completely mineralized. The Se concentration of test solution was analyzed by atomic absorption (Liu \& Gu, 2009).

\subsection{DATA ANALYSES}

The experiment was repeated twice under the same conditions and data were statistically analyzed using the SAS statistical software (version 9.3, SAS Institute, Cary, N.C.). Comparison of the mean data at significance level of $5 \%$ was performed by Least Significant Difference Test.

\section{RESULTS}

\subsection{MORPHOLOGICAL TRAITS}

Comparison of the garden pansy's average height indicated that salinity significantly reduce the plant height. The highest shoot height $(5.75 \mathrm{~cm})$ was observed in the zero salinity and $8 \mathrm{mg} \mathrm{l}^{-1}$ sodium selenate treatment which was not significantly different from other levels of sodium selenate at this salinity level (Table 1). The highest shoot diameter $(5.87 \mathrm{~mm})$ was reported in zero (control) salinity treatments (Table 1). The salinity stress led to a significant decrease in the shoot diameter (Table 2). However, this decrement was lower in the treatments containing sodium selenate and this element moderated the effect of salinity on the shoot diameter (Table 1). Sodium selenate significantly increased the shoot fresh mass. The highest fresh mass (79.33 g) was observed in

Table 1: Interaction effects of different levels of salinity and sodium selenate concentration on shoot height, shoot diameter, fresh weight of the shoot and flower diameter

\begin{tabular}{|c|c|c|c|c|c|}
\hline \multirow[b]{2}{*}{$\begin{array}{l}\text { Salinity level } \\
\left(\mathrm{dS} \mathrm{m}^{-1}\right)\end{array}$} & \multirow[b]{2}{*}{$\begin{array}{l}\text { Sodium selenate con- } \\
\text { centration } \\
\mathrm{mg} \mathrm{l}^{-1}\end{array}$} & \multicolumn{4}{|l|}{ Mean } \\
\hline & & $\begin{array}{l}\text { Shoot height } \\
(\mathrm{cm})\end{array}$ & $\begin{array}{l}\text { Shoot diameter } \\
(\mathrm{mm})\end{array}$ & $\begin{array}{l}\text { Fresh mass of the } \\
\text { shoot } \\
(\mathrm{g})\end{array}$ & $\begin{array}{l}\text { Flower diameter } \\
(\mathrm{cm})\end{array}$ \\
\hline \multirow[t]{4}{*}{0} & 0 & $5.75 \pm 0.21$ & $5.38 \pm 0.21$ & $78.00 \pm 2.31$ & $5.40 \pm 0.41$ \\
\hline & 2 & $5.52 \pm 0.21$ & $5.42 \pm 0.31$ & $78.67 \pm 2.47$ & $5.41 \pm 0.31$ \\
\hline & 4 & $5.57 \pm 0.16$ & $5.72 \pm 0.22$ & $82.83 \pm 2.14$ & $5.72 \pm 0.24$ \\
\hline & 8 & $5.75 \pm 0.17$ & $5.87 \pm 0.17$ & $85.67 \pm 2.19$ & $5.87 \pm 0.34$ \\
\hline \multirow[t]{4}{*}{3} & 0 & $5.28 \pm 0.20$ & $4.65 \pm 0.14$ & $70.50 \pm 1.99$ & $4.65 \pm 0.24$ \\
\hline & 2 & $4.87 \pm 0.31$ & $4.32 \pm 0.15$ & $71.00 \pm 2.09$ & $4.32 \pm 0.25$ \\
\hline & 4 & $5.43 \pm 0.32$ & $4.90 \pm 0.19$ & $74.50 \pm 2.01$ & $4.90 \pm 0.24$ \\
\hline & 8 & $5.28 \pm 0.17$ & $4.93 \pm 0.20$ & $76.83 \pm 2.47$ & $4.93 \pm 0.33$ \\
\hline \multirow[t]{4}{*}{6} & 0 & $3.82 \pm 0.18$ & $3.38 \pm 0.21$ & $56.33 \pm 2.33$ & $3.38 \pm 0.37$ \\
\hline & 2 & $3.95 \pm 0.22$ & $4.02 \pm 0.23$ & $57.50 \pm 2.17$ & $4.02 \pm 0.21$ \\
\hline & 4 & $4.45 \pm 0.19$ & $4.37 \pm 0.31$ & $61.00 \pm 2.17$ & $4.37 \pm 0.14$ \\
\hline & 8 & $4.50 \pm 0.19$ & $4.55 \pm .31$ & $63.67 \pm 2.39$ & $4.55 \pm 0.17$ \\
\hline $\operatorname{LSD}^{*}(p \leq 0.05)$ & & 0.30 & 1.84 & 2.35 & 0.26 \\
\hline
\end{tabular}

${ }^{\star}$ Least Significant Difference. Data presented are mean values obtained from 8 independent replications $( \pm$ SD). 
Table 2: Interaction effects of different types of application and salinity level on shoot diameter and number of flowers

\begin{tabular}{llll}
\hline & & \multicolumn{2}{l}{ Type of application } \\
\cline { 2 - 3 } Trait & Salinity level $\left(\mathrm{dS} \mathrm{m}{ }^{-1}\right)$ & Soil & Foliar \\
\hline Shoot diameter & 0 & $5.46 \pm 0.27$ & $5.73 \pm 0.41$ \\
& 3 & $4.53 \pm 0.36$ & $4.87 \pm 0.28$ \\
& 6 & $3.90 \pm 0.37$ & $4.26 \pm 0.63$ \\
\hline LSD $^{*}(p \leq 0.05)$ & & 1.30 & $15.17 \pm 1.41$ \\
\hline Number of flowers & 0 & $13.75 \pm 0.98$ & $11.17 \pm 1.03$ \\
& 3 & $8.42 \pm 1.02$ & $5.83 \pm 0.95$ \\
\hline $\operatorname{LSD}^{*}(p \leq 0.05)$ & 6 & $4.33 \pm 0.97$ & 0.82 \\
\hline
\end{tabular}

${ }^{*}$ Least Significant Difference. Data presented are mean values obtained from 8 independent replications $( \pm$ SD).

Table 3: Interaction effects of different types of application and sodium selenate concentration on fresh mass of the shoot, number of flowers per plant and flower diameter

\begin{tabular}{lllll}
\hline & $\begin{array}{l}\text { Sodium selenate } \\
\text { concentration } \\
\text { Type of application }\end{array}$ & Mean & & \\
\cline { 2 - 4 } & $\mathrm{mg} \mathrm{l}^{-1}$ & $\begin{array}{l}\text { Fresh mass of the shoot } \\
(\mathrm{g})\end{array}$ & $\begin{array}{l}\text { Number of flowers per } \\
\text { plant }\end{array}$ & $\begin{array}{l}\text { Flower diameter } \\
(\mathrm{cm})\end{array}$ \\
\hline Soil & 0 & $68.11 \pm 2.22$ & $9.33 \pm 0.98$ & $4.47 \pm 0.54$ \\
& 2 & $67.22 \pm 3.14$ & $8.00 \pm 0.24$ & $4.41 \pm 0.50$ \\
& 4 & $71.11 \pm 3.01$ & $9.22 \pm 0.87$ & $4.79 \pm 0.47$ \\
& 8 & $71.44 \pm 3.04$ & $8.78 \pm 0.65$ & $4.86 \pm 0.63$ \\
\hline Foliar & 0 & $68.44 \pm 2.55$ & $9.11 \pm 0.87$ & $4.48 \pm 0.34$ \\
& 2 & $70.89 \pm 3.78$ & $9.89 \pm 0.69$ & $4.76 \pm 0.33$ \\
& 4 & $74.44 \pm 2.98$ & $11.11 \pm 0.67$ & $5.20 \pm 0.41$ \\
\hline $\operatorname{LSD}^{*}(p \leq 0.05)$ & 8 & $79.33 \pm 2.65$ & $12.78 \pm 0.66$ & $5.38 \pm 0.39$ \\
\hline
\end{tabular}

${ }^{\star}$ Least Significant Difference. Data presented are mean values obtained from 8 independent replications $( \pm$ SD).

$8 \mathrm{mg} \mathrm{l}^{-1}$ sodium selenate foliar treatment which was significantly different from other treatments (Table 1). Also, the highest fresh mass $(85.67 \mathrm{~g})$ was achieved in zero salinity (control) treatment with applying $8 \mathrm{mg} \mathrm{l}^{-1}$ sodium selenate (Table 3 ). The highest shoot dry weight (39.01 g) was observed in the sodium selenate foliar treatment at the concentration of $8 \mathrm{mg} \mathrm{l}^{-1}$ and zero salinity (Table 4).

By applying $8 \mathrm{mg} \mathrm{l}^{-1}$ sodium selenate in soil, the number of flowers per plant decreased by $5.89 \%$ compared to the treatment without its usage, while the same concentration with foliar application led to an increment of $40.27 \%$ in the mentioned number (Table 3 ). Salinity stress significantly reduced the flower diameter but this decrease was lower in treatments containing sodium selenate compared to the control one (Table 1). The biggest flower $(5.38 \mathrm{~cm})$ was observed in the foliar treatment of sodium selenate at $8 \mathrm{mg} \mathrm{l}^{-1}$, (Table 3 ). Under the salinity of $6 \mathrm{dS} \mathrm{m} \mathrm{m}^{-1}$, when using sodium selenate in the soil, the flower's fresh and dry mass increased by 11.34 and $10.39 \%$ compared to the control (no sodium selenate usage).

Respectively, while using sodium selenate in terms of foliar application under these conditions, led to the increments of 25.10 and $25.41 \%$ in the fresh and dry mass of the garden pansy's flowers (Table 4 ).

\subsection{CHLOROPHYLL CONTENT AND ENZYME ACTIVITIES}

Salinity of $3 \mathrm{dS} \mathrm{m} \mathrm{m}^{-1}$ resulted in the decreased chlorophyll a and b contents (Table 5). However, under a salinity of $6 \mathrm{dS} \mathrm{m}^{-1}$ with $8 \mathrm{mg} \mathrm{l}^{-1}$ sodium selenate application, the chlorophyll a content increased by $12.93 \%$ rather than not using it (Table 6). Sodium selenate usage in both soil and foliar applications reduced the negative 
Table 4: Interaction effects of different levels of salinity, types of application and sodium selenate concentration on dry massof the shoot, fresh and dry massof the flower

\begin{tabular}{|c|c|c|c|c|c|c|c|}
\hline \multirow{3}{*}{$\begin{array}{l}\text { Salinity level } \\
\left(\mathrm{dS} \mathrm{m}^{-1}\right)\end{array}$} & \multirow{3}{*}{$\begin{array}{l}\text { Sodium selenate } \\
\text { concentration } \\
\mathrm{mg} \mathrm{l}^{-1}\end{array}$} & \multicolumn{6}{|c|}{ Mean } \\
\hline & & \multicolumn{2}{|c|}{ Dry mass of the shoot $(\mathrm{g})$} & \multicolumn{2}{|c|}{$\begin{array}{l}\text { Fresh mass of the flower } \\
(\mathrm{g})\end{array}$} & \multicolumn{2}{|c|}{$\begin{array}{l}\text { Dry mass of the flower } \\
\text { (g) }\end{array}$} \\
\hline & & Soil & Foliar & Soil & Foliar & Soil & Foliar \\
\hline \multirow[t]{4}{*}{0} & 0 & $33.05 \pm 1.02$ & $33.33 \pm 1.24$ & $8.97 \pm 0.97$ & $9.30 \pm 0.64$ & $3.80 \pm 0.4$ & $3.65 \pm 0.3$ \\
\hline & 2 & $32.21 \pm 1.1$ & $34.32 \pm 1.64$ & $9.60 \pm 0.64$ & $9.70 \pm 0.64$ & $3.81 \pm 0.4$ & $3.80 \pm 0.8$ \\
\hline & 4 & $33.33 \pm 0.99$ & $36.88 \pm 1.34$ & $9.77 \pm 0.94$ & $9.90 \pm 0.64$ & $3.37 \pm 0.5$ & $3.87 \pm 0.4$ \\
\hline & 8 & $33.61 \pm 0.97$ & $39.01 \pm 1.33$ & $9.80 \pm 0.63$ & $10.10 \pm 0.74$ & $3.11 \pm 0.6$ & $3.96 \pm 0.6$ \\
\hline \multirow[t]{4}{*}{3} & 0 & $30.07 \pm 0.98$ & $29.93 \pm 1.47$ & $8.63 \pm 0.87$ & $8.53 \pm 0.85$ & $3.28 \pm 0.1$ & $3.33 \pm 0.7$ \\
\hline & 2 & $29.68 \pm 1.01$ & $30.5 \pm 1.06$ & $8.00 \pm 0.74$ & $8.53 \pm 0.64$ & $3.23 \pm 0.4$ & $3.34 \pm 0.7$ \\
\hline & 4 & $32.07 \pm 1.30$ & $31.06 \pm 1.10$ & $8.43 \pm 0.68$ & $8.70 \pm 0.67$ & $2.27 \pm 0.3$ & $3.41 \pm 0.6$ \\
\hline & 8 & $32.21 \pm 1.21$ & $32.91 \pm 1.07$ & $8.30 \pm 0.74$ & $9.10 \pm 0.74$ & $2.22 \pm 0.5$ & $3.57 \pm 0.3$ \\
\hline \multirow[t]{4}{*}{6} & 0 & $24.14 \pm 1.24$ & $24.43 \pm 1.22$ & $5.73 \pm 0.65$ & $5.77 \pm 0.63$ & $2.59 \pm 0.3$ & $2.28 \pm 0.4$ \\
\hline & 2 & $23.31 \pm 1.50$ & $25.86 \pm 1.32$ & $5.67 \pm 0.32$ & $5.90 \pm 0.72$ & $2.53 \pm 0.4$ & $2.34 \pm 0.5$ \\
\hline & 4 & $24.72 \pm 1.37$ & $27.45 \pm 1.64$ & $6.60 \pm 0.54$ & $6.87 \pm 0.63$ & $3.80 \pm 0.3$ & $2.72 \pm 0.5$ \\
\hline & 8 & $24.66 \pm 1.68$ & $29.74 \pm 1.17$ & $6.47 \pm 0.90$ & $7.70 \pm 0.60$ & $3.81 \pm 0.2$ & $3.06 \pm 0.6$ \\
\hline \multicolumn{2}{|c|}{$\mathrm{LSD}^{\star}(p \leq 0.05)$} & \multicolumn{2}{|l|}{1.40} & \multicolumn{2}{|l|}{0.37} & \multicolumn{2}{|l|}{0.12} \\
\hline
\end{tabular}

${ }^{*}$ Least Significant Difference. Data presented are mean values obtained from 8 independent replications $( \pm$ SD).

Table 5: Interaction effects of salinity level and different types of application on chlorophyll a and b contents

\begin{tabular}{lllr}
\hline & & \multicolumn{2}{l}{ Type of application } \\
\cline { 2 - 4 } Trait & Salinity level $\left(\mathrm{dS} \mathrm{m}{ }^{-1}\right)$ & Soil & Foliar \\
\hline Chlorophyll a $\left(\mathrm{mg} \mathrm{g}^{-1}\right)$ & 0 & $0.76 \pm 0.05$ & $0.80 \pm 0.02$ \\
& 3 & $0.62 \pm 0.09$ & $0.70 \pm 0.03$ \\
& 6 & $0.55 \pm 0.08$ & $0.61 \pm 0.04$ \\
\hline LSD $^{*}(p \leq 0.05)$ & & & 0.05 \\
\hline Chlorophyll b $\left(\mathrm{mg} \mathrm{g}^{-1}\right)$ & 0 & $0.26 \pm 0.04$ & $0.27 \pm 0.04$ \\
& 3 & $0.21 \pm 0.03$ & $0.24 \pm 0.03$ \\
\hline $\operatorname{LSD}^{*}(p \leq 0.05)$ & 6 & $0.16 \pm 0.01$ & $0.17 \pm 0.03$ \\
\hline
\end{tabular}

${ }^{\star}$ Least Significant Difference. Data presented are mean values obtained from 8 independent replications $( \pm \mathrm{SD})$.

effect of salinity on the chlorophyll a and b contents (Table 7). Salinity stress resulted in the significant increase of enzyme's activity (Table 5) and the minimum activity of catalase was observed in the $8 \mathrm{mg} \mathrm{l}^{-1}$ sodium selenate in foliar treatment (Table 7 ). The highest activity of superoxide dismutase was achieved in $6 \mathrm{dS} \mathrm{m} \mathrm{m}^{-1}$ salinity treatment and no sodium selenate application (Table 6). This treatment had no significant difference with that of $2 \mathrm{mg} \mathrm{l}^{-1}$ sodium selenate application. Under the salinity stress of $6 \mathrm{dS} \mathrm{m} \mathrm{m}^{-1}$ with $8 \mathrm{mg} \mathrm{l}^{-1}$ sodium selenate application, the enzyme's activity reduced by $26.13 \%$ rather than not applying it (Table 6).

\subsection{CONCENTRATION OF ELEMENTS}

Salinity stress increased $\mathrm{Cl}^{-}$and $\mathrm{Na}^{+}$concentrations of the shoot (Table 8). However, sodium selenate had a moderating effect on them and $\mathrm{Cl}^{-}$concentration of root and shoot were lower in treatments containing this substance (Tables 8 ). $\mathrm{Cl}^{-}$and $\mathrm{Na}^{+}$concentrations of the shoot under the salinity of $6 \mathrm{dS} \mathrm{m}^{-1}$ with $8 \mathrm{mg} \mathrm{l}^{-1}$ application of sodium selenate decreased by 18.65 and $23.92 \%$, respectively compared to the case of not using sodium selenate (Table 8 ). $\mathrm{K}^{+}$concentration in the shoot significantly decreased with increasing salinity stress (Table 
Table 6: Interaction effects of different levels of salinity and sodium selenate concentration on chlorophyll b, catalase and superoxide dismutase enzyme activities

\begin{tabular}{|c|c|c|c|c|}
\hline \multirow[b]{2}{*}{ Salinity level $\left(\mathrm{dS} \mathrm{m}^{-1}\right)$} & \multirow{2}{*}{$\begin{array}{l}\text { Sodium selenate } \\
\text { concentration } \\
\mathrm{mg} \mathrm{l}^{-1}\end{array}$} & \multicolumn{3}{|c|}{ Mean } \\
\hline & & $\begin{array}{l}\text { Chlorophyll a } \\
\left(\mathrm{mg} \mathrm{g}^{-1}\right)\end{array}$ & $\begin{array}{l}\text { Catalase activity } \\
\left(\mu \mathrm{g} \mathrm{H}_{2} \mathrm{O}_{2}^{-1} \mathrm{~min}^{-1} \mathrm{mg}\right)\end{array}$ & 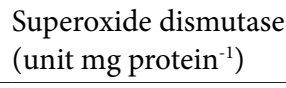 \\
\hline \multirow[t]{4}{*}{0} & 0 & $0.74 \pm 0.04$ & $0.55 \pm 0.04$ & $12.70 \pm 0.17$ \\
\hline & 2 & $0.78 \pm 0.09$ & $0.55 \pm 0.04$ & $13.00 \pm 0.32$ \\
\hline & 4 & $0.79 \pm 0.10$ & $0.54 \pm 0.08$ & $13.03 \pm 0.14$ \\
\hline & 8 & $0.82 \pm 0.06$ & $0.54 \pm 0.07$ & $13.10 \pm 0.17$ \\
\hline \multirow[t]{4}{*}{3} & 0 & $0.65 \pm 0.04$ & $0.80 \pm 0.09$ & $21.60 \pm 0.21$ \\
\hline & 2 & $0.63 \pm 0.11$ & $0.79 \pm 0.06$ & $20.27 \pm 0.32$ \\
\hline & 4 & $0.68 \pm 0.09$ & $0.77 \pm 0.07$ & $17.65 \pm 0.40$ \\
\hline & 8 & $0.69 \pm 0.08$ & $0.76 \pm 0.06$ & $16.28 \pm 0.33$ \\
\hline \multirow[t]{4}{*}{6} & 0 & $0.54 \pm 0.06$ & $0.92 \pm 0.07$ & $25.22 \pm 0.28$ \\
\hline & 2 & $0.55 \pm 0.07$ & $0.89 \pm 0.06$ & $24.80 \pm 0.50$ \\
\hline & 4 & $0.62 \pm 0.06$ & $0.87 \pm 0.08$ & $20.53 \pm 0.34$ \\
\hline & 8 & $0.62 \pm 0.07$ & $0.86 \pm 0.06$ & $18.63 \pm 0.37$ \\
\hline $\operatorname{LSD}^{\star}(p \leq 0.05)$ & & 0.05 & 0.01 & 1.26 \\
\hline
\end{tabular}

${ }^{*}$ Least Significant Difference. Data presented are mean values obtained from 8 independent replications $( \pm S D)$.

Table 7: Interaction effects of different types of application and sodium selenate concentration on chlorophyll a and b and catalase enzyme activity

\begin{tabular}{|c|c|c|c|c|}
\hline \multirow[b]{2}{*}{ Type of application } & \multirow{2}{*}{$\begin{array}{l}\text { Sodium selenate } \\
\text { concentration } \\
\mathrm{mg} \mathrm{l}^{-1}\end{array}$} & \multicolumn{3}{|c|}{ Mean } \\
\hline & & $\begin{array}{l}\text { chlorophyll a } \\
\left(\mathrm{mg} \mathrm{g}^{-1}\right)\end{array}$ & $\begin{array}{l}\text { Chlorophyll b } \\
\left(\mathrm{mg} \mathrm{g}^{-1}\right)\end{array}$ & $\begin{array}{l}\text { Catalase activity } \\
\left(\mu \mathrm{g} \mathrm{H}_{2} \mathrm{O}_{2} \mathrm{~min}^{-1} \mathrm{mg}^{-1}\right)\end{array}$ \\
\hline \multirow[t]{4}{*}{ Soil } & 0 & $0.64 \pm 0.07$ & $0.21 \pm 0.02$ & $0.75 \pm 0.05$ \\
\hline & 2 & $0.63 \pm 0.09$ & $0.20 \pm 0.01$ & $0.76 \pm 0.04$ \\
\hline & 4 & $0.66 \pm 0.10$ & $0.21 \pm 0.3$ & $0.74 \pm 0.03$ \\
\hline & 8 & $0.65 \pm 0.09$ & $0.21 \pm 0.03$ & $0.74 \pm 0.05$ \\
\hline \multirow[t]{4}{*}{ Foliar } & 0 & $0.64 \pm 0.08$ & $0.20 \pm 0.04$ & $0.75 \pm 0.04$ \\
\hline & 2 & $0.67 \pm 0.12$ & $0.21 \pm 0.02$ & $0.72 \pm 0.03$ \\
\hline & 4 & $0.73 \pm 0.11$ & $0.24 \pm 0.02$ & $0.71 \pm 0.03$ \\
\hline & 8 & $0.77 \pm 0.06$ & $0.25 \pm 0.03$ & $0.70 \pm 0.02$ \\
\hline $\mathrm{LSD}^{\star}(p \leq 0.05)$ & & 0.059 & 0.01 & 0.01 \\
\hline
\end{tabular}

${ }^{*}$ Least Significant Difference. Data presented are mean values obtained from 8 independent replications $( \pm S D)$.

9), but sodium selenate application increased this element's concentration (Table 10). Soil and foliar applications with $8 \mathrm{mg} \mathrm{l}^{-1}$ sodium selenate led to the increment in the $\mathrm{K}^{+}$concentration of shoot to the amounts of $4.95 \%$ and $22.62 \%$, respectively (Table 10 ). It was observed the salinity stress decrease the concentration of $\mathrm{P}^{+3}$ in the shoot (Table 9). Applying selenium sodium in the soil and its foliar application at the concentration of $8 \mathrm{mg} \mathrm{l}^{-1}$, increased the concentration of Se in the shoot compared to the control by 63.72 and $68.10 \%$, respectively (Table 10).

\section{DISCUSSION AND CONCLUSION}

It was observed that the salinity stress significantly decreases the plant height of garden pansy but this decrement is lower in sodium selenate containing treatments and its higher levels improved the height and reduced the 
Table 8: Interaction effects of different levels of salinity and sodium selenate concentration on $\mathrm{Cl}^{-}$and $\mathrm{Na}^{+}$concentration in shoot

\begin{tabular}{|c|c|c|c|}
\hline \multirow[b]{3}{*}{$\begin{array}{l}\text { Salinity level } \\
\left(\mathrm{dS} \mathrm{m}^{-1}\right)\end{array}$} & \multirow[b]{3}{*}{$\begin{array}{l}\text { Sodium selenate concentration } \\
\mathrm{mg} \mathrm{l}^{-1}\end{array}$} & \multicolumn{2}{|c|}{ Mean } \\
\hline & & \multicolumn{2}{|c|}{ Shoot } \\
\hline & & $\begin{array}{l}\mathrm{Cl}^{-} \\
\left(\mathrm{mg} \mathrm{g}^{-1}\right)\end{array}$ & $\begin{array}{l}\mathrm{Na}^{+} \\
\left(\mathrm{mg} \mathrm{g}^{-1}\right)\end{array}$ \\
\hline \multirow[t]{4}{*}{0} & 0 & $13.17 \pm 0.33$ & $1.58 \pm 0.16$ \\
\hline & 2 & $12.67 \pm 0.24$ & $1.67 \pm 0.10$ \\
\hline & 4 & $13.17 \pm 0.22$ & $1.63 \pm 0.09$ \\
\hline & 8 & $13.17 \pm 0.19$ & $1.70 \pm 0.2$ \\
\hline \multirow[t]{4}{*}{3} & 0 & $20.83 \pm 0.34$ & $1.98 \pm 0.12$ \\
\hline & 2 & $21.17 \pm 0.42$ & $1.90 \pm 0.10$ \\
\hline & 4 & $21.17 \pm 0.32$ & $1.47 \pm 0.13$ \\
\hline & 8 & $19.17 \pm 0.23$ & $1.43 \pm 0.08$ \\
\hline \multirow[t]{4}{*}{6} & 0 & $32.17 \pm 0.23$ & $2.72 \pm 0.08$ \\
\hline & 2 & $31.17 \pm 0.15$ & $2.40 \pm 0.12$ \\
\hline & 4 & $30.00 \pm 0.17$ & $2.12 \pm 0.13$ \\
\hline & 8 & $26.17 \pm 0.19$ & $2.07 \pm 0.11$ \\
\hline $\operatorname{LSD}^{\star}(p \leq 0.05)$ & & 2.15 & 0.20 \\
\hline
\end{tabular}

${ }^{*}$ Least Significant Difference. Data presented are mean values obtained from 8 independent replications $( \pm$ SD).

Table 9: Interaction effects of different types of application and salinity level on $\mathrm{Cl}^{-}$and $\mathrm{K}^{+}$concentration in shoot and $\mathrm{Cl}^{-}$and $\mathrm{P}^{+3}$ concentration in root

\begin{tabular}{|c|c|c|c|c|c|}
\hline \multirow[b]{3}{*}{ Type of application } & \multirow[b]{3}{*}{ 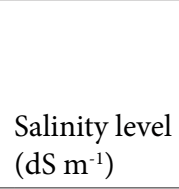 } & \multicolumn{4}{|c|}{ Means } \\
\hline & & \multicolumn{2}{|c|}{ Shoot } & \multicolumn{2}{|c|}{ Root } \\
\hline & & $\begin{array}{l}\mathrm{Cl}^{-} \\
\left(\mathrm{mg} \mathrm{g}^{-1}\right)\end{array}$ & $\begin{array}{l}\mathrm{K}^{+} \\
\left(\mathrm{mg} \mathrm{g}^{-1}\right)\end{array}$ & $\begin{array}{l}\mathrm{Cl}^{-} \\
\left(\mathrm{mg} \mathrm{g}^{-1}\right)\end{array}$ & $\begin{array}{l}\mathrm{P}^{+3} \\
\left(\mathrm{mg} \mathrm{g}^{-1}\right)\end{array}$ \\
\hline \multirow[t]{3}{*}{ Soil } & 0 & $13.00 \pm 0.43$ & $24.55 \pm 1.1$ & $33.25 \pm 0.33$ & $2.63 \pm 0.09$ \\
\hline & 3 & $21.58 \pm 0.32$ & $15.38 \pm 0.9$ & $43.83 \pm 0.18$ & $2.58 \pm 0.08$ \\
\hline & 6 & $31.58 \pm 0.32$ & $18.96 \pm 0.8$ & $79.33 \pm 0.32$ & $2.02 \pm 0.10$ \\
\hline \multirow[t]{3}{*}{ Foliar } & 0 & $13.08 \pm 0.15$ & $27.69 \pm 1.2$ & $32.67 \pm 0.43$ & $3.10 \pm 0.08$ \\
\hline & 3 & $19.58 \pm 0.21$ & $16.02 \pm 1.0$ & $44.33 \pm 0.39$ & $2.56 \pm 0.06$ \\
\hline & 6 & $28.17 \pm 0.27$ & $21.72 \pm 0.8$ & $76.58 \pm 0.51$ & $1.90 \pm 0.06$ \\
\hline $\operatorname{LSD}^{\star}(p \leq 0.05)$ & & 1.52 & 1.01 & 1.38 & 0.23 \\
\hline
\end{tabular}

${ }^{\star}$ Least Significant Difference. Data presented are mean values obtained from 8 independent replications $( \pm$ SD).

influence of the salinity stress. The negative effects of salinity on the plant growth are due to the low osmotic potential of soil solution (osmotic stress), special ionic effects (salinity stress), nutrients imbalance or combination of these factors. Hence, as the plant grows under salinity conditions, its photosynthetic activity decreases and results in a decrement in the shoot height. As the minerals concentration increases, the osmotic pressure of the soil solution increases, thus increasing the amount of energy the plant requires in order to absorb water from the soil, which reduces water absorption, increases respiration and decreases plant height and yield (Malash et al., 2008; Hawrylak et al., 2019). Decrease in the height of other ornamental plants under the salinity stress has also been reported (Mirlotfi et al., 2015; Nofal et al., 2015; Kozminska et al., 2017). Salinity stress significantly decreased the shoot fresh and dry mass, but in the treatments containing sodium selenate, the fresh mass decrement was lower. Under the salinity stress, as the salt concentration increases, the osmotic potential of the solution increases, water absorption and cells' turgor pressure decrease consequently. Water withdrawal from the cells prevents 
Table 10: Interaction effects of different levels of type of application and sodium selenate concentration on $\mathrm{K}$ and Se concentration in shoot and $\mathrm{Cl}^{-}$and $\mathrm{K}$ concentration in root

\begin{tabular}{|c|c|c|c|c|c|}
\hline \multirow[b]{3}{*}{ Type of application } & \multirow{3}{*}{$\begin{array}{l}\text { Sodium selenate } \\
\text { concentration } \\
\mathrm{mg} \mathrm{l}^{-1}\end{array}$} & \multicolumn{4}{|c|}{ Mean } \\
\hline & & \multicolumn{2}{|c|}{ Shoot } & \multicolumn{2}{|c|}{ Root } \\
\hline & & $\begin{array}{l}\mathrm{K}^{+} \\
\left(\mathrm{mg} \mathrm{g}^{-1}\right)\end{array}$ & $\begin{array}{l}\mathrm{Se}^{+} \\
\left(\mathrm{mg} \mathrm{g}^{-1}\right)\end{array}$ & $\begin{array}{l}\mathrm{Cl}^{-} \\
\left(\mathrm{mg} \mathrm{g}^{-1}\right)\end{array}$ & $\begin{array}{l}\mathrm{K}^{+} \\
\left(\mathrm{mg} \mathrm{g}^{-1}\right)\end{array}$ \\
\hline \multirow[t]{4}{*}{ Soil } & 0 & $19.39 \pm 0.7$ & $10.44 \pm 0.91$ & $53.56 \pm 1.05$ & $14.44 \pm 1.1$ \\
\hline & 2 & $18.73 \pm 0.9$ & $12.44 \pm 0.82$ & $54.22 \pm 1.03$ & $17.56 \pm 0.9$ \\
\hline & 4 & $19.99 \pm 0.8$ & $19.56 \pm 0.87$ & $51.33 \pm 1.00$ & $18.78 \pm 1.0$ \\
\hline & 8 & $20.40 \pm 0.8$ & $28.78 \pm 0.94$ & $49.44 \pm 1.07$ & $21.89 \pm 1.2$ \\
\hline \multirow[t]{4}{*}{ Foliar } & 0 & $19.42 \pm 0.9$ & $10.56 \pm 0.76$ & $53.67 \pm 1.10$ & $14.33 \pm 0.9$ \\
\hline & 2 & $20.08 \pm 1.0$ & $13.44 \pm 0.86$ & $51.22 \pm 1.70$ & $14.33 \pm 0.8$ \\
\hline & 4 & $22.64 \pm 0.8$ & $20.78 \pm 0.69$ & $50.44 \pm 1.98$ & $16.67 \pm 1.02$ \\
\hline & 8 & $25.10 \pm 1.1$ & $33.11 \pm 0.29$ & $49.44 \pm 1.76$ & $17.89 \pm 1.03$ \\
\hline $\mathrm{LSD}^{\star}(p \leq 0.05)$ & & 1.17 & 1.30 & 1.60 & 1.38 \\
\hline
\end{tabular}

${ }^{\star}$ Least Significant Difference. Data presented are mean values obtained from 8 independent replications $( \pm$ SD).

them from growing. On the other hand, with shrinking and falling leaves, the source of assimilates production in the plant decreases. Therefore, the amount of material reaching the cells is significantly reduced, which eventually causes both reducing number and size of the cells and consequently reduce the fresh and dry mass of the organs (Rawson et al., 1998). In general, the increasing soil salinity causes a significant reduction in the growth and crop yield. Salinity affects all major processes such as growth, photosynthesis, protein synthesis, lipid metabolism and energy. Further to these, it affects all stages of plant life from germination to biomass and seed productions (Pardia et al., 2004). In this study sodium selenate application improved the growth of garden pansy. Consistent with these results, Turakainen (2007) in a greenhouse experiment showed that selenium-treated potato (Solanum tuberosums L.) had higher yield rather than the control, which might be due to the antioxidant effects in delaying the plant aging.

Salinity stress led to the significant decrease in the chlorophyll content of the garden pansy. Also, a significant decrease in the chlorophyll volume with increasing $\mathrm{NaCl}$ concentration in other ornamental plants has been previously reported (Bayat et al., 2012; Al Hassan et al., 2015, 2016a, b; Kumar et al., 2017). The reducing photosynthetic pigments appear to be a general response to the salinity stress (Parihar et al., 2015). In addition, salinity stress causes premature leaf aging, chloroplast breakage and reduced chlorophyll content. Chlorophyll content declination results in reduced photosynthesis and plants which maintain more chlorophyll content during the stress, have higher photosynthetic efficiency and are resistant to it (Sharma \& Dubey, 2005). Application of selenium as foliar solution increased the chlorophyll $\mathrm{a}$ and $\mathrm{b}$ content in the garden pansy. Confirming these results, Shahzadi et al. (2017) reported that foliar application of selenium leads to an increment in the chlorophyll content of barely (Hordeum vulgare L.). Application of appropriate levels of selenium reduces damage to chloroplasts and thus increases the leaves' chlorophyll content (Chu et al., 2010; Yao et al., 2011; Malik et al., 2012; Wang, 2011). Significant increase has been observed in the catalase enzyme's activity and superoxide dismutase enzyme's activity of garden pansy under salinity stress. Decrease in the active oxygen species within the plants exposed to the drought and salinity stresses has been observed by using selenium in canola (Hasanuzzaman et al., 2011; Hasanuzzaman \& Fujita, 2011) and white clover (Trifolium repens L.) seedlings (Wang, 2011).

Salinity led to the increment in $\mathrm{Na}^{+}$and $\mathrm{Cl}^{-}$concentration in shoots and root of the garden pansy. $\mathrm{Na}^{+}$accumulation in the plants is usually associated with inhibition of enzymatic activities, physiological processes and $\mathrm{K}^{+}$concentration decrease as these two elements compete for passing across the membrane's width by carriers (Rodríguez-Navarro, 2000). In addition, $\mathrm{K}^{+}$decrement has negative effects on the photosynthesis, osmotic regulation, protein biosynthesis and trigger pressure (Gierth \& Mäser, 2007). However, compared to the control, the application of $8 \mathrm{mg} \mathrm{l}^{-1}$ selenium with foliar and soil application, led to the $\mathrm{K}^{+}$increments of 22.62 and $4.95 \%$ in the shoot, 34.03 and $19.89 \%$ in the root, respectively. Similarly, Pazurkiewicz et al. (2008) reported that the selenium application causes an increment in the $\mathrm{K}^{+}$content of maize. The adjustment of the absorption and distribution of some essential elements by selenium is an im- 
portant mechanism in the reaction to the antioxidants involved in reducing the levels of reactive oxygen species (Feng et al., 2013). Application of selenium in terms of both soil and foliar applications increased this element's concentration in the garden pansy's shoots but this increment was higher for foliar application. The efficiency decrement of the increasing selenium in the plant by its soil application might be due to less plant access to this element in the soil. Confirming the results, Wanga et al. (2013) reported that both foliar and soil applications of selenium have positive effect on increasing selenium concentration in some plants without any negative on other nutrients. Furthermore, they reported that foliar application of selenium is more effective than the soil counterpart.

Salinity stress significantly reduced the plant's height, number and diameter of the flower, dry and fresh mass of the shoot, and flower, chlorophyll content, $\mathrm{P}^{+3}$ and $\mathrm{K}^{+}$concentrations of the garden pansy but the activity of antioxidant enzymes (catalase and superoxide dismutase) increased under these conditions. The sodium selenate application was observed to reduce the influences of salinity stress on the investigated traits of the garden pansy. The sodium selenate foliar application at the concentration of $8 \mathrm{mg} \mathrm{l}^{-1}$, was the best treatment for increasing the shoot growth as well as flower growth under the salinity stress.

\section{REFERENCES}

Al Hassan, M, Morosan, M, López-Gresa, MP, Prohens, J, Vicente, O and Boscaiu, M. (2016 a). Salinity-induced variation in biochemical markers provides insight into the mechanisms of salt tolerance in common (Phaseolus vulgaris) and runner (P. coccineus) beans. International Journal of Molecular Science, 17, 1582. https://doi.org/10.3390/ ijms 17091582

Al Hassan, M, López-Gresa, MP, Boscaiu, M and Vicente, O. (2016 b). Stress tolerance mechanisms in Juncus: responses to salinity and drought in three Juncus species adapted to different natural environments. Functional Plant Biology, 43, 949-960. https://doi.org/10.1071/FP16007

Al Hassan, M, Martínez Fuertes, M, Ramos Sánchez, FJ, Vicente, $\mathrm{O}$ and Boscaiu, M. (2015). Effects of salt and water stress on plant growth and on accumulation of osmolytes and antioxidant compounds in cherry tomato. Notulae Botanicae Horti Agrobotanici, 43, 1-11. https://doi.org/10.15835/ nbha4319793

Ashraf, M and Harris, PJC. (2004). Potential biochemical indicators of salinity tolerance in plants. Plant Science Journal, 166, 3-16. https://doi.org/10.1016/j.plantsci.2003.10.024

Ashraf, M, Ahmad, R, Bhatti, AS, Afzal, M, Sarwar, A, Maqsood, MA, and Kanwal, S. (2010). Amelioration of salt stress in sugarcane (Saccharum officinarum L.) by supplying $\mathrm{K}$ and silicon in hydroponics. Pedosphere, 20, 153-162. https://doi. org/10.1016/S1002-0160(10)60003-3

Bayat, H, Alirezaie, M and Neamati, H. (2012). Impact of exogenous salicylic acid on growth and ornamental characteristics of calendula (Calendula officinalis L.) under salinity stress. Journal of Stress Physiology Biochemistry, 8, 258- 267.

Bocchini, M, D’Amato, R, Ciancaleoni, S, Fontanella, MC, Palmerini, CA, Beone, GM and Businelli, D. (2018). Soil Selenium (Se) Biofortification changes the physiological, biochemical and epigenetic responses to water stress in )Zea mays L.( by inducing a higher drought tolerance. Frontier Plant Science, 9, 389. https://doi.org/10.3389/ fpls.2018.00389

Bradford, MM. (1976). A rapid and sensitive method for the quantitation of microgram quantities of protein utilizing the principle of protein-dye binding. Annal Biochemistry, 72, 248-254. https://doi.org/10.1016/0003-2697(76)905273

Cassaniti, C, Romano, D and Flowers, TJ. (2012). The response of ornamental plants to saline irrigation water. In: Irrigation-Water Management, Pollution and Alternative Strategies. I. Garcia-Garizabal (Ed.), IntechOpen, London, UK, 131-158. https://doi.org/10.5772/31787

Bybordi, A. (2016). Effect of zeolite, selenium and silicon on yield, yield components and some physiological traits of canola under salt Stress conditions. Iranian Journal of Field Crop Research, 14, 154-170.

Chu, JZ, Yao, XQ, and Zhang, ZN. (2010). Responses of wheat seedlings to exogenous selenium supply under cold stress. Biological Trace Element Research, 136, 355-363. https:// doi.org/10.1007/s12011-009-8542-3

Diao, M, Ma, L, Wangm, J, Cui, J, Fu, A and Liu HY. (2014). Selenium promotes the growth and photosynthesis of tomato seedlings under salt stress by enhancing chloroplast antioxidant defense shoot. Journal of Plant Growth Regulation, 33, 671-682. https://doi.org/10.1007/s00344-014-9416-2

Djanaguiraman, M, Durga Devi, D, Shanker, AK, Sheeba, JA and Bangarusamy U. (2005). Selenium - an antioxidative protectant in soybean during senescence. Plant and Soil, 272, 77-86. https://doi.org/10.1007/s11104-004-4039-1

Feng, R, Wei, C and Tu, S. (2013). The roles of selenium in protecting plants against abiotic stresses. Environmental Experimental Botany, 87, 58-68. https://doi.org/10.1016/j. envexpbot.2012.09.002

Germ, M, Stibilj, V and Kreft, I. (2007). Metabolic importance of selenium for plants. European Journal of Plant Science Biotechnology, 1, 91-97

Giannopolitis, C.N. and Ries, S.K. (1977) Superoxide dismutases. Occurrence in higher plants. Plant Physiology, 59, 309- 314. https://doi.org/10.1104/pp.59.2.309

Gierth, M and Mäser, P. (2007). K transporters in plants-Involvement in $\mathrm{K}^{+}$acquisition, redistribution and homeostasis. FEBS Letters, 581, 2348- 2356. https://doi.org/10.1016/j. febslet.2007.03.035

Grigore, MN, Boscaiu, M, Llinares, J and Vicente, O. (2012). Mitigation of salt stress-induced Inhibition of Plantago crassifolia reproductive development by supplemental calcium or magnesium. Notulae Botanicae Horti Agrobotanici, 40, 58-66. https://doi.org/10.15835/nbha4028246 
Habibi, G. and S. Sarvary. 2015. The Roles of Selenium in Protecting Lemon Balm against Salt Stress. Iranian Journal of Plant Physiology, 5, 1425-1433.

Hasanuzzaman, M, Nahar, K and Fujita, M. (2013). Plant response to salt stress and role of exogenous protectants to mitigate salt induced damages. In: Ecophysiology and responses of plants under salt stress. pp. 25-87. https://doi. org/10.1007/978-1-4614-4747-4_2

Hasanuzzaman, M and Fujita, M. (2011). Selenium pretreatment up regulates the antioxidant defense and methylglyoxal detoxification syshoot and confers enhanced tolerance to drought stress in rapeseed seedlings. Biological Trace Element Research, 143, 1758-1776. https://doi.org/10.1007/ s12011-011-8998-9

Hasanuzzaman, M, Anwar Hossain, M, and Fujita, M. (2010). Selenium in higher plants: physiological role, antioxidant metabolism and abiotic stress tolerance. Journal of Plant Science, 5, 354-375. https://doi.org/10.3923/jps.2010.354.375

Hasegawa, P M and Bressan, RA. (2000). Plant cellular and molecular responses to high salinity. Annual Review of Plant Physiology and Plant Molecular Biology, 51, 463-99. https:// doi.org/10.1146/annurev.arplant.51.1.463

Hashem, HA, Hassanein RA, Bekheta MA and El-Kady, FA. (2013). Protective role of selenium in canola (Brassica napus L.) plant subjected to salt stress. Egyptian Journal of Experimental Biology, 9, 199-211.

Hawrylak-Nowak, B, Rubinowska, K, Molas, J, Woch, W, Matraszek-Gawron, R and Szczurowska, A. (2019). Seleniuminduced improvements in the ornamental value and salt stress resistance of Plectranthus scutellarioides (L.) R. Br. Folia Horticulturae, 31, 213-221. https://doi.org/10.2478/ fhort-2019-0016

Hoagland, DR and Arnon, DI. (1950). The Water-Culture Method for Growing Plants without Soil. California Agricultural Experiment Station, Circular-347.

$\mathrm{Hu}, \mathrm{Y}$ and Schmidhalter, U. (2005). Drought and salinity: a comparison of their effects on mineral nutrition of plants. Soil Science and Plant Nutrition, 168, 541-549. https://doi. org/10.1002/jpln.200420516

Kaur, N., Sharma, S., Kaur, S., Nayyar, H., (20140. Selenium in agriculture: a nutrient or contaminant for crops? Archives of Agronomy and Soil Science, 60, 1593-1624. https://doi.org/1 0.1080/03650340.2014.918258

Khan, MS, Ahmad, D and Khan, MA. (2015). Trends in genetic engineering of plants with $(\mathrm{Na}+\mathrm{H}+)$ antiporters for salt stress tolerance. Biotechnology Biotechnological Equipment, 29, 815-825. https://doi.org/10.1080/13102818.2015.10608 68

Kozminska, A, Al Hassan, M, Kumar, D, Oprica, L, Martinelli, F, Grigore, MN, Vicente, O and Boscaiu, M. (2017). Characterizing the effects of salt stress in Calendula officinalis $\mathrm{L}$. Journal of Applied Bot any and Food Quality, 90, 323 - 329

Kumar, D, Al Hassan, M, Naranjo, MA, Agraval, V, Boscaiu, $\mathrm{M}$ and Vicente, O. (2017). Effects of salinity and drought on growth, ionic relations, compatible solutes and activation of antioxidant shoots in oleander (Nerium oleander L.). PLoS ONE, 12, 1-22. https://doi.org/10.1371/journal. pone. 0185017

Liang, Y, Zhang, W, Chen, Q, Liu, Y and Ding, R. (2006). Effect of exogenous silicon ( $\mathrm{Si}$ ) on $\mathrm{H}^{+}$-ATPase activity, phospholipids and fluidity of plasma membrane in leaves of saltstressed barley (Hordeum vulgare L.). Environmental Experimental Botany, 57, 212-219. https://doi.org/10.1016/j. envexpbot.2005.05.012

Lichtenthaler, HK and Wellburn, AR. (1983). Determination of total carotenoids and chlorophyll a and b of leaf extracts in different solvents. Biochemical Society Transactions, 603, 591-592. https://doi.org/10.1042/bst0110591

Liu, KL and Gu, ZX. (2009). Selenium accumulation in different brown rice cultivars and its distribution in fractions. Journal of Agricultural and Food Chemistry, 57, 695-700. https://doi.org/10.1021/jf802948k

Mahajan, S and Tuteja, N. (2005). Cold, salinity and drought stresses: an overview. Archives of Biochemistry and Biophysics, 444, 139-158. https://doi.org/10.1016/j.abb.2005.10.018

Malash, NM, Flowers TJ and Ragab, R. (2008). Effect of irrigation methods, management and salinity of irrigation water on tomato yield, soil moisture and salinity distribution. Irrigation Science, 26, 313-323. https://doi.org/10.1007/ s00271-007-0095-7

Malik, JA, Goel, S, Kaur, N, Sharma, S, Singh, I and Nayyar, H. (2012). Selenium antag-onises the toxic effects of arsenic on mungbean (Phaseolus aureus Roxb.) plants by restricting its uptake and enhancing the antioxidative and detoxification mechanisms. Environmental Experimental Botany, 77, 242-248. https://doi.org/10.1016/j.envexpbot.2011.12.001

Matraszek, R, Hawrylak-Nowak, B and Chwil, M. (2015). Protein hydrolysate as a component of salinized soil in the cultivation of Ageratum houstonianum Mill. (Asteraceae). Acta Agrobotics, 68, 247-253. https://doi.org/10.5586/ aa.2015.028

Matos, RP, Lima, VM, Windmüller, CC and Nascentes, CC. (2017). Correlation between the natural levels of selenium and soil physicochemical characteristics from the Jequitinhonha Valley (MG). Brazilian Journal of Geochemistry Exploration, 172, 195-202. https://doi.org/10.1016/j.gexplo.2016.11.001

Mirlotfi, A, Bakhtiari, S and Bazrgar, AB. (2015). Effect of seed priming on germination and seedling traits of Marigold (Calendula officinalis) at saline condition. Biological Forum and International Journal, 7, 1626-1630.

Munshower, FF. (2018). Practical Handbook of Disturbed Land Revegetation: 0. CRC Press. https://doi. org/10.1201/9781351075923

Munns, R and Tester, M. (2008). Mechanisms of salinity tolerance. Annual Review of Plant Biology, 59, 651-681. https:// doi.org/10.1146/annurev.arplant.59.032607.092911

Nofal, FH, El-Segai, MU and Seleem, EA. (2015). Response of Calendula officinalis L. plants to growth stimulants under salinity stress. Journal of Applied Engineering Science, 15, 1767-1778.

Parihar, P, Singh, S, Singh, R, Singh VJ, Prasad and SM. (2015). Effect of salinity stress on plants and its tolerance strategies: a review. Environmetal Science and Pollution Research, 22, 4056-4075. https://doi.org/10.1007/s11356-014-3739-1

Pezzarossa, B, Remorini, D, Gentile, ML and Massai, R. (2012). Effects of foliar and fruit addition of sodium selenate on selenium accumulation and fruit quality. Journal of Scien- 
tific Food Agriculture, 92, 781-786. https://doi.org/10.1002/ jsfa.4644

Pazurkiewicz-Kocot, K, Kita, A and Pietruszka, M. (2008). Effect of selenium on magnesium, iron, manganese, copper, and zinc accumulation in corn treatedbyindole-3-aceticacid. Communications in Soil. Science and Plant Analysis, 39, 2303-2318. https://doi.org/10.1080/00103620802292343

Rawson, HM, Iong, MJ and Munns, R. (1988). Growth and development in $\mathrm{NaCl}$ treated plants. Journal of Plant Physiology, 15, 519-527. https://doi.org/10.1071/PP9880519

Rios, JJ, Blasco, B, Cervilla, LM, Rosales, MA, Sanchez-Rodriguez, E, Romero, L and Ruiz, JM. (2009). Production and detoxification of $\mathrm{H}_{2} \mathrm{O}_{2}$ in lettuce plants exposed to selenium. Annals Applied Biology, 154, 107-116. https://doi. org/10.1111/j.1744-7348.2008.00276.x

Rodríguez-Navarro, A. (2000). K transport in fungi and plants. Biochimia et Biophysica Acta, 1469, 1-30. https://doi. org/10.1016/S0304-4157(99)00013-1

Satyendra, NR, Stephan, WB, Gossett, DR, Lucas and MC. (1999). Antioxidant response to salt stress during fiber development in cotton ovules. Journal of Cotton Science, 30, 11-15.

Shahid, M, Niazi, NK, Khalid, S, Murtaza, B, Bibi, I, Rashid, MI. (2018). A critical review of selenium biogeochemical behavior in soil-plant system with an inference to human health. Environmetal Pollution, 234, 915-934. https://doi. org/10.1016/j.envpol.2017.12.019

Shahzadi, I, Iqbal, M, Rasheed, R, Arslan Ashraf, M, Perveen, S and Hussain, M. (2017). Foliar application of selenium increases fertility and grain yield in bread wheat under contrasting water availability regimes. Acta Physiologiae Plantarum, 39, 173. https://doi.org/10.1007/s11738-017-2477-7

Sharma, PR and Dubey, S. (2005). Drought induces oxidative stress and enhances the activities of antioxidant enzymes in growing rice seedlings. Plant growth regulation, 46, 209221. https://doi.org/10.1007/s10725-005-0002-2
Supriatin, S, Weng, L and Comans, RN. (2015). Selenium speciation and extractability in Dutch agricultural soils. Science of the Total Environment, 532, 368-382. https://doi. org/10.1016/j.scitotenv.2015.06.005

Tan, LC, Nancharaiah, YV, van Hullebusch, ED and Lens, PN. (2018) Selenium: environmental significance, pollution, and biological treatment technologies. In: Anaerobic Treatment of Mine Wastewater for the Removal of Selenate and its Co-Contaminants, (pp. 9-71). CRC Press. https://doi. org/10.1201/9780429448676-2

Turakainen, M. (2007). Selenium and its effects on growth, yield and tuber quality in potato. University of Helsinki, Helsinki (Doctor thesis).

Vukics, V, Kery, A, and Guttman, A. (2008). Analysis of polar antioxidants in heartsease (Viola tricolor L.) and garden pansy (Viola $\mathrm{x}$ wittrockiana Gams.). Journal of Caring Sciences, 46, 823-827. https://doi.org/10.1093/chromsci/46.9.823

Wang, CQ. (2011). Water-stress mitigation by selenium in Trifolium repens L. Journal of Soil Science and Plant Nutrition, 174, 276-282. https://doi.org/10.1002/jpln.200900011

Wang, J, Wang, Z, Mao, H, Zhao, H and Huang, D. (2013). Increasing Se concentration in maize grain with soil- or foliar-applied selenate on the Loess Plateau in China. Field Crops Research, 150, 83-90. https://doi.org/10.1016/j. fcr.2013.06.010

Yao, X, Chu, J, He, X, and Ba, C. (2011). Protective role of selenium in wheat seedlings subjected to enhanced UV-B radiation. Russain Journal of Plant Physiology, 58, 283-289. https://doi.org/10.1134/S1021443711020257

Zhu, Z., Chen, Y., Zhang, X., Li, M., 2016. Effect of foliar treatment of sodium selenate on postharvest decay andquality of tomato fruits. Scientia Horticulturae, 198, 304-310. https://doi.org/10.1016/j.scienta.2015.12.002 